\title{
Subject Reference Start Time
}

National Cancer Institute

\section{Source}

National Cancer Institute. Subject Reference Start Time. NCI Thesaurus. Code C158692.

The time a subject reference began. 